Review Article

\title{
MENTAL HEALTH ISSUES AND RELEVANT LEGISLATION IN A DEVELOPING COUNTRY
}

\section{Shafquat Inayat}

Department of College of Nursing, Independent University Hospital, Narwala Road, Kothi Sadat, Marzipura road, Faisalabad, Pakistan.

Correspondence: Shafquat Inayat. Email: shafquat.rana@hotmail.com

\begin{abstract}
Mental health legislation compiles and integrates fundamental doctrine, principles, goals, objectives and mental health policy. This legislation is required to assure that the self-respect and the dignity of patients is conserved and that their fundamental rights are protected. This article considers legislation in the Indo-Pak subcontinent, especially the Mental Health Act in Pakistan, and asserts that the act has limitation that serve as a barrier to mental health services currently provided in Pakistan. The purpose of this article is to identify the mental health legislation in a developing country like Pakistan. It also emphasizes the need of a modern mental health law that provides priority to protect the rights of patient with mental disorder to promote development of community based care and improves its access.
\end{abstract}

Keywords: Mental health, Pakistan mental law, lunacy act.

\section{Introduction}

Pakistan is a 6th world most populated South East Asian country with a population of 194.9 million (1). Majority $(61.24 \%)$ of the population live in rural areas, $24 \%$ economy is agriculture dependent population $(2,3)$. According to the Multidimensional Poverty Index (MPI) of 2015-2016, four out of ten (39\%) Pakistani lived in multidimensional poverty (4). Islam is the main religion and mental illnesses are stigmatized and usually perceived to have paranormal causes $(5,6,7)$. The traditional healers and religious person are the mental health service providers (7).

Mental health is the most neglected field in Pakistan, and 50 million people suffering from extremely devastating mental health disorders (8). Pakistan is a country having lowest patient-to-doctor ratios for mental illness in the world (9). According to the World Health Organization (WHO), there are only 400 psychiatrists and 5 psychiatric hospitals are available in Pakistan with a patient-doctor ratio of $1: 500,000$ (10).

In mental health illnesses, depression and anxiety disorders are highest in Pakistani society followed by, schizophrenia, post-traumatic stress disorder, bipolar disorder, substance and alcohol misuse (11). A study from Karachi found $40.6 \%$ depression and anxiety in elderly population in which women were affected more than men (12). A comparative study conducted in rural Northern Punjab (Rawalpindi) found high depression and anxiety rate in women (25\%) as compared to the men (10\%) (13). According to the last national survey, there are estimated four million drug addict in Pakistan creating the public health dilemma $(14,15)$.

Mental health problems are increasing rapidly due to insurgency, current violent situation, political chaos and frequent verdict in the society of Pakistan (7). The objective of this article is to review the mental health law and legislation in Pakistan. Furthermore, the current article highlighted the changes and amendments which are occurring with the passage of time in the history of mental health law in Pakistan. Moreover, recommended the better way forward for mental health legislative stakeholders to improve the situations for mental health in Pakistan.

\section{History of Mental Health Law in Pakistan}

Historical background of lunatic act started in the era of 1324 in Britain King Edward II. Further, recognized by the name of criminal lunatic's act in 1800, followed by changed in asylums act in 1808 and finally approved in 1890 as "lunacy act" (16). The lunacy act later reformed in 1913 underneath the mental deficiency act which was recognized by a board of control to check out the asylums. After World War II in 1959 the act was upgraded and later abolished in 1983 and the Mental Health Act (MHA) came into being in the 30th of September $1983(17,18)$. 
Mental health law was introduced in Indo-Pak subcontinent which was announced as a Lunacy Act (1912) (19). After the establishment of Pakistan most of the laws practiced in the British Sub-continent were taken as it is. The mental health legislation was also one of the laws which were adopted as it is and the Lunacy Act (1912) was used for psychiatric patients (17). This act was declared to those persons having with mental illness as "Lunatics" or "idiots of unsound mind (19). The main focus of this act was to purge the mentally ill personnel from the society and keeping them in Asylums (17). So far, the terms like 'lunatics' and 'asylums' were part of our mental health law for 2001, although the government at that time had enough insight to produce the Mental Health Ordinance (MHO) in Pakistan, bringing it somewhat at part of the 21st century (20).

In Pakistan, until 2001, the major source of laws for the treatment of mentally ill individual was the Lunacy Act of 1912 (16). The lunacy act was divided into four major parts incorporating with important definition and terms, documentations relating to response, precaution, and management of individuals suffering from mental illness highlighting, practical rules for establishing whether or not an individual is mentally ill (8). On the basis of need assessment, the law was found to be terribly inadequate and obsolete to combat the growing need of the mentally ill persons and society, it was obligatory for the amendment in the lunacy act. (21)

So far, the protection of mentally ill person's mental health ordinance (MHO), 2001 was introduced that addressed human and civil rights of persons with mental illness. According to this ordinance patient has the right of informed consent, right and privilege to confidentiality, right to protection of property and assets, punitive measures against abusive treatment (17). The significant change in the $\mathrm{MOH}$ was the establishment of the federal ministry health authority and strict punishments who did criminal offences against the mentally ill patients i.e. fine and imprisonment and six months to five years according to the severity of the crime (19). One of the significant legal issues with respect to individual who are mentally disorders is the concern of their criminal and civil liability. In the Britain law, person with mentally disorders qualify the "defense of insanity and automatism" that leads to decrease in their obligation for criminal offences, while $\mathrm{MHO}$ was not be able to address this issue, mentally disordered prisoners continue to suffer within the criminal justice system of our country (17).

Additionally, there was no practical application of provincial implementation of mechanism, and law execution agencies were ineffective or absent and none of the effort was made to implement the law (17). At 8th April, 18th amendment (2010) to the constitution was established, and responsibilities was decentralized to provinces, due to partially ineffectiveness in enforcement of MHO 2001, provinces undertaken to rewrite with fewer limitations; thus, currently in Pakistan
MHO, 2013 applicable of Sindh province and MHO 2001 replaced by the Punjab Mental Health act (MHA) (amendments) 2014 applicable to Punjab. (22)

However, the MHO is not clear in terms of the paper work that required further direction on detaining a patient in a hospital and neither does it stated which authority will supervise these proceedings (17).

\section{Contributing Factor of Mental Health IIIness in Pakistan}

Mental health problems in Pakistan are increasing rapidly due to psychological perspectives (stress, anxiety and depressive disorders etc.), socio-cultural disparities (stigma, discrimination, prejudice, cultural conflict, and tradition etc.), economic instability (unemployment and poverty), persistent violent situation and political turmoil $(14,21)$. According to a report conducted by Human Right Commission of Pakistan (HRCP) revealed that among the psychological disorders, $34 \%$ population of the country experienced from some form of mental illness (22).

A systematic review on psychological disorders reveled risk factors positively associated with female gender, low level of education, sociopolitical instability, economic insecurity and regional conflict (18). Furthermore, medical personnel tend to focus on medical models, without any regard to the patients psycho-social, cultural and economic perspective (14, 23).

It creates a vast grey area either judgment about the mental health of a person or group would be dependent on relative psychosocial or sociocultural norms (14).

Modern world emphasize on personal autonomy, individuality and objectivity (13). On the contrary, in Pakistani society values like orthodoxy, submission to authority and passive behavior characterize as normal and any refusal to these norms is considered as divergent (14). Certain psych socio and cultural practices in our society considered as unusual even to abnormal (7). A society like Pakistan where aggression, violence, social conservatism, helplessness is the norm of the day, and where people get frustrated in getting their due services from government and nongovernment institutions, where corruption is considering as a right and not an exception, life of an ordinary person become miserable and depressive (14).

Mental health services are still under-resourced in terms of trained professionals as the most of the people concerned for treatment are not facilitated properly (8). Additionally, a result of the social stigma associated with psychiatric disorders, a general misconception in the community that mental illnesses are due to the possession of 'Jin' or evil eyes or 'Jadoo' (magic), seemingly confirmed when patients consult traditional healers (14). On the contrary patients are often suffered by mental disorders (15). A public perception of every third individual generally state or confine mental health as health of mad (pagaloon ki 
sehat) (24). In the light above mentioned mental health issues are fabricated by sociocultural and political influences on the population of Pakistan having mental health illness faced lots of problems for example; people who are suffering mental health illness are treated un- humanly by the families $(14,25)$. Furthermore most of the families claim the owner of the property and business of the persons, who are suffering from mental disorders (18).

\section{Table 1: Comparison of mental health acts in Pakistan}

\begin{tabular}{|c|c|c|c|}
\hline Issue & Lunacy act of 1912 & $\begin{array}{l}\text { Mental health ordinance of } \\
2001\end{array}$ & $\begin{array}{l}\text { The Constitution (Eighteenth Amendment) } \\
\text { Act, } 2010\end{array}$ \\
\hline $\begin{array}{l}\text { Meaning and } \\
\text { terminologies }\end{array}$ & $\begin{array}{l}\text {-Referred to persons with } \\
\text { mental illness as "Lunatics" or } \\
\text { "idiots of unsound mind" } \\
\text {-Keeping ancient, imprecise } \\
\text { and undefined terminology } \\
\text { which is not used in the } \\
\text { modern world. }\end{array}$ & $\begin{array}{l}\text { Used more humanitarian } \\
\text { based and updated } \\
\text { terminology } \\
\text { e.g. "mental illness", } \\
\text { "psychiatric facility", "care in } \\
\text { the community" etc. }\end{array}$ & $\begin{array}{l}\text { Process of decentralization of ministries and } \\
\text { power and give greater power to provinces }\end{array}$ \\
\hline $\begin{array}{l}\text { Content or main } \\
\text { emphasis }\end{array}$ & $\begin{array}{l}\text {-Removing persons with } \\
\text { mental illness away from } \\
\text { conventional society and } \\
\text { keeping them under } \\
\text { supervisory care or "asylums" } \\
\text { 'Protecting' the society from } \\
\text { persons with mental illness and } \\
\text { insane persons }\end{array}$ & $\begin{array}{l}\text {-Addressed human and civil } \\
\text { rights of persons with mental } \\
\text { illness } \\
\text {-Informed consent } \\
\text {-Right and opportunity for } \\
\text { confidentiality } \\
\text {-Right to protection of } \\
\text { property and resources } \\
\text {-Disciplinary measures } \\
\text { against abusive treatment }\end{array}$ & $\begin{array}{l}\text { Mental health Ordinance becomes a victim of } \\
18^{\text {th }} \text { Amendment due to decentralization of } \\
\text { ministries and greater power given to province }\end{array}$ \\
\hline
\end{tabular}

\section{Policy Implication}

In case of the mental health policy of Pakistan, there have been problems since its commencement (17). The mental health scenario in Pakistan required persistent attention from professional bodies working in academics and professionals in the mental health field and policy makers (14). For the policymakers, there is a need to examine the criminal and the mental health legislations available for offender applying fitness to stand trial issues as well as applying petition insanity at the time of the crime known as the insanity defense. To combat these challenges, a clear framework of legislation is 
required for limiting the over representation of mentally ill offender in the criminal judiciary system $(22,26)$. Furthermore, proper training programs in psychiatry for health care professional in the primary health care units could bring substantial development in the mental health care e.g. early diagnosis, proper treatment plan and referral to professional psychiatric service (27).

In addition, there should be center of excellence institutes of international standard, where the mental health professional enhance their academic capacities to specialization, post graduate and doctorate level (28). Moreover, there should be collaborative program among, traditional healers, community workers, public health sectors, NGOs and teachers to discuss mental health issues and its challenges (28).

\section{Conclusion}

The journey of mental health law from lunacy act to the $\mathrm{MOH} 2001$ is an important development that is came into being on the basis of changing need of the mentally ill patients by the Federal Mental Health Authority. Mental health situation in Pakistan is not up-to-the-mark both in terms of trained staff and patients care/facilities. We have, at this stage may not achieve the WHO goal "Health for all" even in the next decades. Mental health illness is related to bigger problem which can be addressed by the government and the society at the same point by improving overall socioeconomic, cultural and political situations. Keeping in mind the social barriers (Belief System and Social Stigma) and professional barriers (trained personnel and adequate services), there is, of course, a shortage of vigorous involvement by government, donors and groups representing mental health workers, patients and their families need to work together to increase mental health services in term of prevention, treatment and rehabilitation. It is high time for our generation of psychiatrists to play their dynamic role towards promotion of mental health awareness with certainly, strongly developed concept of professional responsibility. In this way we can 'identify, prevent, treat and defeat mental illnesses at various levels.

\section{References}

1. Pakistan population 2017 | Current population of Pakistan [Internet]. Countrymeters.info. 2017 [cited 10 June 2017]. Available from: http://countrymeters.info/en/Pakistan\#populatio n_2016

2. Rural population (\% of total population) in Pakistan [Internet]. Tradingeconomics.com. 2017 [cited 10 June 2017]. Available from: https://tradingeconomics.com/pakistan/ruralpopulation-percent-of-total-population-wbdata.html

3. Agriculture Statistics | Pakistan Bureau of Statistics [Internet]. Pbs.gov.pk. 2017 [cited 10 June 201017 . Available from: http://www.pbs.gov.pk/content/agriculture- statistics

4. Pakistan's new poverty index reveals that 4 out of 10 Pakistanis live in multidimensional poverty [Internet]. UNDP in Pakistan. 2017 [cited 10 Jun e $\left.20 \begin{array}{lllll} & 0 & 1\end{array}\right]$. Ava ila ble from: http://www.pk.undp.org/content/pakistan/en/ho me/presscenter/pressreleases/2016/06/20/paki stan-s-new-poverty-index-reveals-that-4-out-of10-pakistanis-live-in-multidimensionalpoverty.html

5. Hussain F. Mental illness in Pakistan: Exorcising the jinn of stigma. DAWN [Internet]. 2015 [cited 10 June 2017]. Available from: https://www.dawn.com/news/1198350

6. Ciftci A, Jones N, Corrigan P. Mental Health Stigma in the Muslim Community. Journal of Muslim Mental Health. 2013;7(1).

7. Karim S, Saeed K, Rana M, Mubbashar M, Jenkins R. Pakistan mental health country profile. International Review of Psychiatry. 2004;16(1-2):83-92.

8. Opinion: Pakistan's mental health problem [Internet]. America.aljazeera.com. 2017 [cited 10 June 2017]. Available from: http://america.aljazeera.com/opinions/2015/10/ pakistans-mental-health-problem.html

9. Mian A. The News [Internet]. 2016 [cited 19 April $\left.\begin{array}{llll}2 & 0 & 1 & 7\end{array}\right]$. A v a i l a b I e f rom : https://www.thenews.com.pk/latest/156099-50million-people-with-mental-disorders-inPakistan

10. Mahmood A. Mental illness in Pakistan: The toll of neglect. DAWN [Internet]. 2014 [cited 19 April 2017 ]. Available from: https://www.dawn.com/news/1133196

11. Rafiqu I. Mental health. Pakistan Journal of Medical Research. 2013;52(4):1-2.

12. Bhamani MA, Karim MS, Khan MM. Depression in the elderly in Karachi, Pakistan: a cross sectional study. BMC Psychiatry. 2013, 13:181.

13. Mumford DB, Minhas FA, Akhtar I, Akhtar S, Mubbashar $\mathrm{MH}$. Stress and Psychiatric disorder in Urban Rawalpindi: a community survey. Br J Psychiatry. 2000; 177:557-62

14. Khalily TM. Personality characteristics of addicts and non-addicts determined through Rorschach findings. Pakistan Journal of Psychology. 2009;40(1):3-15

15. Anti-Narcotics Force (ANF) Islamabad national drug assessment study in Pakistan (200607) Islamabad, Pakistan: Anti Narcotic Force Ministry of Narcotics Control; 2006. http://america.aljazeera.com/opinions/2015/10/ pakistans-mental-health-problem.html

16. British Academy. Protecting the property of the mentally ill: the judicial solution in nineteenth century lunacy law [Internet]. 2013. Available from: https://ore.exeter.ac.uk/ 
repository/bitstream/handle/10036/4359/Stebbi ngs_PROTECTIN G\% 20 THE\% 20 PROPERTY\%200F\%20THE\%20MENTALLY\% 20ILL.pdf?sequence $=5$

17. Abbasi Y. Mental Health Ordinance 2001- Is it really being used? Journal of Pakistan Medical Association. 2008;58(10):578-579.

18. Mirza I. Risk factors, prevalence, and treatment of anxiety and depressive disorders in Pakistan: systematic review. BMJ. 2004;328(7443):794-0.

19. Gilani A, Gilani U, Kasi P, Khan M. Psychiatric Health Laws in Pakistan: From Lunacy to Mental Health. PLoS Medicine. 2005;2(11):317.

20. Narayan C, Shikha D. Indian legal system and mental health. Indian Journal of Psychiatry. 2013;55(6):177.

21. Government of Pakistan (2001) Mental Health Ordinance, 2001. Available: http:??www.emro. who.int/MNH/WHD/Pakistan-Ordinance.pdf. Accessed 11 August 2005

22. Daily Times | Forensic psychiatry in Pakistan [Internet]. Dailytimes.com.pk. 2017 [cited 13

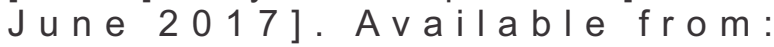
http://dailytimes.com.pk/opinion/03-Apr16/forensic- psychiatry-in-Pakistan

23. Sorsdahl K. Traditional Healers in the Treatment of Common Mental Disorders in South Africa: Erratum. The Journal of Nervous and Mental Disease. 2010;198(9):695

24. Hussain S. Mental Health in Pakistan: Myths and Facts I JPMS Medical Blogs [Internet]. Blogs.jpmsonline.com. 2017 [cited 12 June $\left.\begin{array}{llll}2 & 0 & 1 & 7\end{array}\right]$. A $v$ a i l a b le from : http://blogs.jpmsonline.com/2014/06/17/mental -health-in-pakistan-myths-and-facts/

25. Yusuf S. Breaking point: Mental health in Pakistan [Internet]. DAWN.COM. 2017 [cited 12 June 2017 ]. Available from: https://www.dawn.com/news/1137302

26. Husain M. Blasphemy laws and mental illness in Pakistan. Psychiatric Bulletin. 2014;38(1):4044.

27. Gater R. Mental health and service development in Pakistan. Mental health in the new Millennium: Freud, Freedom and Future. In: Mubashar $\mathrm{MH}$, Humayun A, editors. Proceedings of the 13th International Psychiatric Conference. Pakistan: Rawalpindi Institute of Psychiatry; Jan 2001. pp.356-68.

28. Niaz U. Women's mental health in Pakistan. World Psychiatry 2004;3(1):60-2. 